Book Review

\title{
Family and Career. Future plans for university students. Ed. Ágnes Engler.
}

\author{
Csaba Jancsák ${ }^{1}$ \\ Recommended citation: \\ Jancsák, Cs. (2020). Family and Career. Future plans for university students. Ed. Ágnes Engler. [Review of the book \\ Future plans for university students, by Engler, Á.] Central European Journal of Educational Research, 2(3), 99-101. \\ https://doi.org/10.37441/CEJER/2020/2/3/8534
}

Bibliography of the reviewed book: Engler, Á. (2018). Future plans for university students. Debrecen: Center for Higher Education Research and Development. p. 212., ISBN 978-615-80077-6-4.

\section{Introduction}

Although a number of researchers from the classics of sociology to today's health sociologists have argued that social capital available in the family is more effective than many other types of capital, the proportion of young people committed to family is in steep decline. Ágnes Engler and her research group are looking for answers to their question: how today's students view starting a family.

The cover of the book depicts the conflicts of the modern man between happy family life and career with fun, cartoon-like interpretations that encourages the potential reader. The book was published in the Education Research Library series which intends to publish the latest CHERD research findings.

The studies illustrate students' futures, perceptions of relationships and family formation, as well as the relationship between post-graduate career plans and family life, and the relationship between labour market expectations and career breaks. It also included the beliefs about paternal roles, using charts and tables, and the new roles of higher education in creating a family-friendly institutional atmosphere.

\section{Review}

Rather than simply presenting a summary, we highlight some exciting results that arouse interest. Ágnes Engler's introductory study on the professional and private futures of Hungarian students demonstrates that the institution of marriage and the family are very important values for the students, which significantly shape their future orientation and career planning. Most students are committed to starting a family, and many are planning to raise two or more children. However, it is essential to achieve a work-life balance, for which future generations of intellectuals can make informed and conscious choices. In making these decisions, students attach importance to the development of a family-friendly attitude in the world of work, to which the microclimate of higher education institutions contributes an important sensitizing effect. The second study of the book discusses the connection between relationship commitments and family intentions. Ágnes Engler analyses when, under what circumstances, and in what form, students plan to establish relationships. The results show that the majority of respondents prefer stable and long-term relationships. Nine out of ten university students have a prominent role in marriage planning, but they also face the fact that in our fast-paced world, individual consumer society works against the birth and lasting existence of relationships. Their beliefs reflect this when they defined the intrinsic, universal values (loyalty, acceptance, trust) attached to a mature personality as a prerequisite for marriage, as opposed to material values or the possession of consumer goods. The study also reveals the results of the research, which shows the value orientation and future planning of students. The proportion of children they want is 2.5. More than half of students consider the age between 25 and 30 to be ideal for having their first child. Another important finding of the study is that the patterns of the original family significantly determine the family formation plans of the young. The larger the family in which they grew up, the more likely they are to have two or more children.

\footnotetext{
${ }^{1}$ University of Szeged, Juhász Gyula Faculty of Education, csaba.jancsak@gmail.com
} 
Judit Fináncz's Study on Family Formation and Future Plans in a Regional Approach explores the regional differences in students 'families of origin, and the relationship between students' residences and family attitudes and plans. The overall fertility rate of the Hungarian population shows significant regional differences, with more children being born in economically disadvantaged regions with less educated populations and very few in more modern and developed regions. The author notes that students' attitudes towards family formation and future are also significantly differentiated by the distance between the place of residence and the location of the higher education institution. For example, when it comes to having their first child, students in the capital who live with their parents are more flexible, while students coming from rural areas, due to the difficult housing conditions, having a child is postponed until after graduation.

Tímea Ceglédi's work, Is Subordinate Privacy Essential for a Career examines the relationship behaviour of students who successfully study despite their disadvantage. Long-term relationships, cohabitation and marriage are the most common among resilient ones, while members of the control group with a favourable family background prefer shorter-term and looser relationships, the most important thing for them in the relationship being to have a similar family background. Resilient students often choose partners that are not associated with university. According to family sociologists, the more culturally homogeneous the relationship is, the more stable the relationship. Thus, the pursuit of homogamy by higher status may not be an endeavour to social exclusion but a factor contributing to stability based on social experience.

Veronika Bocsi's study, Career with Family or Career Alone, covers and scrutinizes the impact of family formation plans on work values. The study concludes that the male and female sub-sample includes young people who face the dilemma of career-family reconciliation but is not primarily gender-specific. Higher salary earnings affect men more, while the social dimension of employment affects women more. The author proves that it is not true that higher career goals are seen by students only if they do not plan for a more stable relationship or if they do not want to have children.

The next study of the book, conducted by Anikó Üröginé Ács and Balázs Bovei Kovács, was written on the subject of career breaks and the realistic feasibility of young people planning their career. The authors' main finding is that, in international comparison, Hungarian students plan to have their first child earlier than their Western European counterparts, which is related to the fact that the majority of Hungarian young people are committed to starting a family. At the same time, however, they also consider it necessary to shape the world of work and the supportive attitude of employers in terms of reconciling family and career.

Attila Pongrácz and Zsuzsanna Márkus in their analysis of Family and Career Issues in the Light of Study Commitment found an increasing number of students in higher education; moreover, they discovered that within the years spent in higher education student work experience was increasingly studied in terms of gaining work experience. As a result of their qualitative study, the authors conclude that in students' 5- or 10-year plans, starting a family is a milestone ahead of career development efforts and yet combining the two with conscious planning of time-to-family relationships was still a viable option.

Orsolya Joó and Tamara Takács investigated the characteristics of family formation of teachers participating in the research. The focus of their interest was the extent to which changing family formation tendencies influence the ideas of the future generation of educators. The study concludes that there is no significant difference between teacher and non-teacher students' perceptions of starting a family, but that teacher education (educational science?) students have competencies in parenting transfer, which is critical, because they also include family-related issues as elements of the teaching profession.

Ágnes Dusa's study, Future Plans in the Light of Foreign Mobility, argues for highly thought-provoking and even incisive results when she argues that positive mobility attitudes are undermined by foreign mobility. Not surprisingly, in terms of foreign plans and overall vision, the gloomiest students are those who want to live abroad. As far as the relationship is concerned, it can be stated that even within the basically pro-marital students, the proportion of those who intend to remain in marriage is the highest among those who would definitely like to stay in Hungary. The longer the respondent student plans to live abroad, the more likely is the proportion of looser types of cohabitation.

The primary goal of Hajnalka Fényes's and Brigitta Fehérvári's Assessment of the Father's Role in Students in Higher Education was to map the attitudes of students in the higher education system towards fatherhood. The authors conclude that the majority of students think in family-oriented and intermediate ways, that is, more modern-minded father roles. However they strongly prefer career and material prosperity, and this factor is also the main determinant of the mixed, material-focused paternal attitude. Men are more insecure, women think more about father roles, students from rural areas think more traditionally, and those who were in relationships during the research prefer family-oriented father roles. 
Katinka Bacskai's The Impact of Religiousness on Attitudes towards Family Creation and Childbirth raises a very important question in the society of declining religiosity. In recent years, domestic literature has made a major contribution to exploring the situation of religious families. Hakkel Tünde eds. 2016. Family Report. Budapest: L \& \# 39; Harmattan is a good example of this, in which a study on the impact of religiosity on family stability and the quality of parenting found that parents with a community religion in parenting are significantly more active than others in three areas. They learn more about the student's leisure time outside the home, involve the student more intensively in homework, and organize joint family cultural programs more frequently. The analysis also showed the significant advantage of homogamous religious couples practicing religion in maintaining family stability. The study concludes that religiosity is present in the student community at the same time among lower-status students and higher-status students, and that more religious students have a more well-established and conservative view of family formation.

The dilemmas of the birth and vivacious existence of family-friendly higher education can be found in the pages written by Hajnalka Kamuti and Balázs Horváth. One of the most important new social roles of the Hungarian higher education system, which is still evolving today, is the formation of a family-friendly attitude and its institutional development. This, however, requires not only a change in approach but also significant investment in infrastructure and cubature, which entails the creation and operation of services complementary to traditional teaching and training roles in higher education. For example, designing baby-mama-dad rooms, changing rooms, or reorganizing customer reception times in a family-friendly way. The authors argue that family-friendly measures have a positive impact on the institutional microclimate and affect the lives of students and workers alike and support the development of quality higher education.

\section{Conclusions}

The book is cordially recommended to readers interested in family and career planning who want to gain a deeper understanding of the world of higher education and students' perceptions and future orientations.

(C) 2020 by the authors. Submitted for possible open access publication under the terms and conditions of the Creative Commons Attribution (CC BY) license (http://creativecommons.org/licenses/by/4.0/). 